\title{
SIGNIFICACIÓN DEL ESPACIO Y MODOS DE PRODUCCIÓN SÍGNICA EN LA ISLA DEL DÍA DE ANTES, DE UMBERTO ECO
}

\author{
Rocco MANGIERI \\ Universidad de Los Andes (Venezuela) \\ Consejo de Desarrollo Científico y Humanístico CDCHT
}

Resumen: Este ensayo está orientado a la descripción y al análisis semiótico del sentido y la semiosis del espacio en la novela de Umberto Eco. Estamos particularmente interesados en las interrelaciones entre el modelo generativo y el interpretativo y sus aplicaciones a un objeto complejo: la construcción y organización semiótica del espacio en el discurso narrativo de Eco y de las relaciones entre la teoría y la ficción.

Abstract: This essay is oriented to description an semiotic analysis of the sense and semiosis of space in Umberto Eco's novel. We are specifically interested in the semiotic interrelations between the generative and interpretative models and his applications in a complex object: the construction and semiotic organization of the space in the narrative discourse of Eco and the relationships between the theory and fiction. 
Palabras clave: Espacio. Semiótica. Dimensión narrativa. Semiosis.

Key words: Space. Semiotic. Narrative dimension. Semiosis.

\section{ROBERTO DE LA GRIVE DECIDE DIBUJAR EL DAPHNE...}

Debía convertirse en estrella fija y obligar el intruso a moverse... (LIDDA, La isla del día de antes, p. 195).

Nelle repliche il tipo é diverso dall'occorrenza. Il tipo prescribe solo le propietá essenziali che l' occorenza debe realizzare per essere giudicata una replica soddisfacente (...) Questa lista coincide sotto alcuni aspetti alle scale di iconicitá proposte da Abraham Moles... (U. Eco, Trattato di semiotica generale, Milano: Bompiani, 1975: 245).

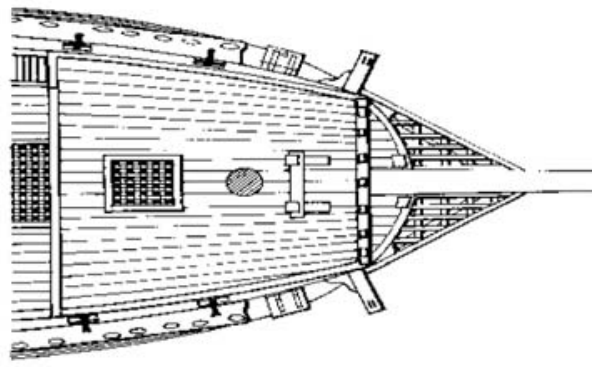

A partir del quinto día, si nos guiamos por el narrador-transcriptor de la novela, Roberto De La Grive, náufrago a pesar suyo y entretejido en una trama de poder y misterio que no le pertenece, ya posee en su mente los contornos de un mapa más o menos completo del barco que lo había alojado: un navío holandés, un fluyt de carga, misteriosamente abandonado a poca distancia de una exótica isla del Pacífico, hipotético lugar por donde pasaría el meridiano divino y sobre el cual es confinado por el destino de los mares luego del aparatoso naufragio del Amarillis. Pero todavía la información y la semiosis del reconocimiento (el «primer» modo de producción sígnica del Trattato di semiotica generale, de Eco) es insuficiente. Los itinerarios verticales y desplazamentos horizontales, realizados por Roberto De La Grive, gentilhombre atrapado en contra de su voluntad en el misterioso cálculo de las longitudes y los polvos de la simpatía universal, aunque le han permitido 
hacerse una imagen más detallada de algunos espacios interiores, no son signos suficientes para configurar un esquema general, una cartografía confiable del Daphne. En el transcurso de los capítulos 18 y 20 el sujeto interpretante cumplirá con la tarea de dibujar o cartografiar el navío de manera minuciosa con la finalidad de poder encontrar el escondite del intruso: ese fabuloso y fabulador personaje llamado Caspar Wanderdrosel, enésimo tutor del personaje de este trans-género novelesco que mima también al perfil del bildungsroman occidental.

Esta operación semiótica de dibujo es importante también para el lector pues ofrece finalmente la posibilidad de comparar la imagen arquitectónica que éste pudiese haberse construido a lo largo del relato. No cabe duda que para el sujeto explorador y desde la mirada de una semiótica del espacio, el pasaje descriptivo-narrativo del trazado del dibujo del Daphne significa el final del proceso de reconocimiento que fundamenta toda la actividad semiósica de Roberto desde el abordaje y hasta esta fase de la posesión de un mapa global del espacio que señala al mismo tiempo el significado de una apropiación completa del navío como habitáculo y como casa. Evidentemente como todo mapa (y sobre todo en referencia a la teoría del sujeto del Trattato y de Semiotica e filosofia del linguaggio) se trata de un interpretante que cubre una porción del objeto y que siendo conjetural puede ser falsable (Popper, 1972, 1974) (Eco, 1992: 18, 149-150, 153-155). Por qué no recordar a Korzinsbky («...el mapa no es el territorio»):

En cualquier caso, hacia la tarde del quinto día había decidido llevarse a aquella parte de la bodega que todavía no había visitado, por debajo del pañol de los bastimentos. Daba en la cuenta de que en el Daphne habiase aprovechado al máximo el espacio y entre la segunda puente y la bodega habian sido montados mamparas y cacharros, con la finalidad de obtener compartimentos conectados por escalas de tojines, y había entrado en la corulla de las jarcias, tropezando con rollos de cuerdas de todo tipo, aún impregnadas de agua marina. Había bajado aún más abajo y había dado en la segunda carina, entre cajones y envoltorios de diferentes tipos (...) Luego regresó a la bodega, imaginémonos en qué estado, y se detuvo sintiendo el hedor de la podredumbre que había calado la sentina. Más abajo no se podía ir.

Debía ir por tanto hacia atrás, hacia la popa, pero la lámpara estaba apagándose y había tropezado con algo y había comprendido que estaba procediendo entre el lastre (...). Precisamente en la bodega, entre manchas de agua y desechos de comida estibada, divisó la huella de un pie... (LIDDA, p. 165). 
El protagonista, si seguimos fieles al narrador, desciende de nuevo por la zona de proa, atravesando el pañol de bastimento y la despensa. Roberto se había percatado antes de la compartimentación del espacio inferior y necesita averiguar bien entre sus intersticios. Accede entonces al espacio de las jarcias donde se almacenan las cuerdas y baja hacia el espacio más inferior de las bodegas y las sentinas. Se da cuenta de que más abajo no puede irse porque se trata de un límite último del barco. Debe entonces desplazarse, a través de las bodegas, hacia la zona de popa y en ese recorrido descubre una huella que confirma definitivamente la presencia a bordo de un intruso. El combustible ya agotado de su lámpara le impide continuar y sale a cubierta, al espacio del combés. El sujeto observador ha cumplido, al igual que antes, un movimiento de ida y venida, de inmersión y de ascensión, conjuntamente con un breve desplazamiento horizontal en el fondo último de la nave (las bodegas y sentinas). Ya casi anochece y el texto aprovecha para ofrecernos una descripción del paisaje que contrasta con todas las anteriores. El espacio percibido, a través de una mirada mucho más subjetivante y plena de metáforas, pone en evidencia una valoración disfórica del objeto. En este pasaje descriptivo, construido a la manera de un cuadro fijo (nos recuerda las obras de Turner o Vermeer), en el ocaso figurativizado como unidad espacio-temporal incoativa y detensiva se expresa de algún modo el estado a la vez pasional y cognitivo del sujeto, en el cual no hay distinciones cortantes entre el signo de la emoción y el signo del entendimiento:

Era el ocaso. Era la primera puesta de sol que veía, después de cinco días de noches, albas y auroras. Pocas nubes negras casi paralelas bordeaban la Isla más lejana para espesarse a lo largo de la cima, y de allí flameaban como saetas, hacia el sur. La costa destacábase sombría contra el mar ya color de tinta clara, mientras el resto del cielo aparecíase de un color manzanilla, mortecino y enervado, como si el sol no estuviera celebrando allá atrás su sacrificio... (LIDDA, p. 166).

Con el objetivo de alterar los nervios de su «enemigo» se dirige al tabuco de los relojes y los pone a funcionar de nuevo. Dormirá allí en medio de «ese puente sembrado de máquinas del tiempo». El proceso de exploración y búsqueda continua en la mañana del sexto día: sobresaltado por unas grullas que al despertar se encontraban picoteando entre los relojes y creyéndola obra de su enemigo desconocido baja en tropel hacia la bodega cayendo y lastimándose un brazo:

El objeto que ocupaba el nuevo espacio era un órgano, que tenía encima unas veinte cañas, de cuyas aberturas salían notas de la melodía (...). En la parte su- 
perior estaban, en el centro, las cañas, a los lados movíanse unos pequeños autómatas. (...) Los martillitos de diferentes pesos, producían sonidos argentinos que no desentonaban con la melodía cantada por las cañas (...). Al lado del órgano estaba fijada una máquina hidráulica de cristal, una cantimplora que recordaba por su forma el capullo del gusano de seda... (LIDDA, p. 193).

Prueba, sin suerte, sobre su herida la teoría del polvo de simpatía y, ya muy bebido, se duerme en la leñera. Desciende la noche. A partir del séptimo día Roberto De La Grive efectúa las últimas exploraciones internas hasta el momento del dibujo del Daphne:

a) Descubre otros dos espacios hacia la zona de proa. Uno de ellos recuerda una wünderkamern o cámara de las maravillas repleta de animales embalsamados, insectos inmovilizados dentro de trozos de ámbar, frascos con animales que flotaban en extraños líquidos, objetos varios. Roberto lo identifica como el aposento de un naturalista o un erudito (LIDDA, p. 188).

b) Para descubrir el escondite del intruso vuelve a la leñera (en la zona más baja de popa) y encuentra un nuevo espacio que denomina soda o sota, el pañol para el bizcocho:

$Y$ aquí descubre un objeto muy relevante para la historia: un símil de la famosa Specola Melitensis que el intruso (el Padre Caspar, eminente erudito y naturalista) utilizará para medir la Longitud y ubicación de aquel paradisíaco paraje que él cree que es la Isla Salomónica, correspondiente al sistema de astronomía sagrada, a partir del cual Dios divide el tiempo del no-tiempo: el antes y el después de la creación. En ese meridiano, que atraviesa los dos promontorios de la Isla, ha tenido principio el primer día de la creación (LiDDA, pp. 211-212).

Por allí debería pasar el meridiano $180^{\circ}$.

c) Encuentra entre estos artefactos un largavistas más potente, un telescopio. Una hipérbole de los ojos, como le llama metafóricamente, destinado a la observación minuciosa del cielo.

d) Roberto decide averiguar si más abajo de ese espacio existe otro lugar. Debe arrastrarse a gatas y comprobar finalmente que más allá de ese fondo se encuentra ya el mar. Ha dado con el fondo de bodegas y con el casco. Más allá no puede haber nada más.

e) Movido por los extraños sonidos, similares a una multitud de flautas, Roberto se dirije de nuevo al tabuco de los relojes (zona de popa, de- 
bajo de la timonera) para descubrir, luego de arrancar una gran tela en tromple l'oeil que servía de fondo al teatro de los relojes, un órgano cuya descripción textual nos trae la imagen de los mecanismos acústicos y sonoros de la Misurgia Universalis del ábate Kircher (Gómez de Liaño, 2001).

Sentado en la mesa, muy posiblemente en la cámara de oficiales bien provista de instrumentos y pergaminos o papel, Roberto inicia decidido el trazado del perfil del barco, tomando como referencia el Amarillis: primero, realiza un corte longitudinal y luego, una suerte de vista desde arriba, a vuelo de pájaro o planimetría. La descriptio del narrador configura un proceso de dibujo que parece ir de izquierda a derecha y de arriba hacia abajo. Primero se trazan en vertical los espacios de popa, luego los de proa. Enseguida se trata de visualizar el espacio debajo del combés: el entrepuente, las bodegas y las sentinas. El dibujo permite detenerse en algunos espacios que probablemente pudieran alojar al intruso:

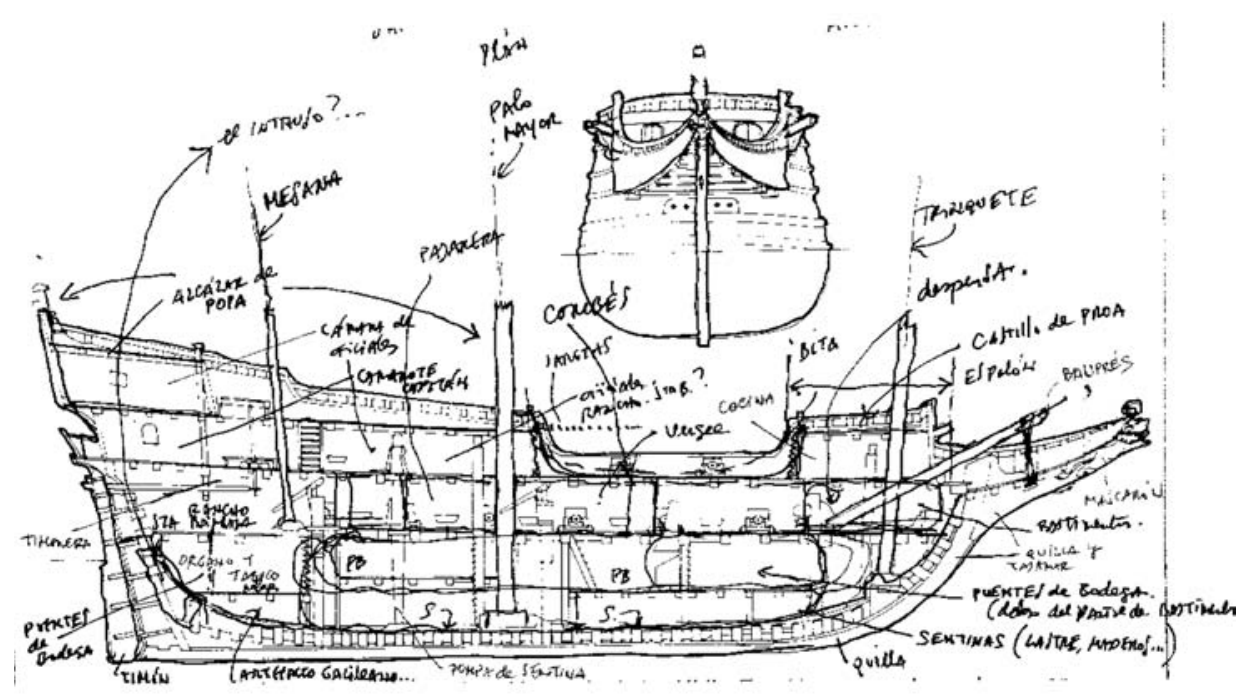

Se había sentado, por tanto, a la mesa y había dibujado el perfil del navío, inspirándose tanto en la estructura del Amarillis como en lo que había visto hasta entonces en el Daphne. Así pues, decíase, tenemos los alojamientos del alcázar y debajo la timonera; aún más abajo (pero aún en el primer puente), la cámara de oficiales y el rancho de Santa Bárbara. Éste debe dar a popa y 
allende ese límite no puede haber ya nada. Todo esto está al mismo nivel que la cocina en el castillo de proa. Después el bauprés se apoya sobre otra parte sobrealzada y allá — si interpreto bien las apuradas perifrasis de Robertotenían que estar aquellos beques en los que, con las asentaderas hacia fuera, hacíanse en la época las propias necesidades. Si se bajaba debajo de la cocinilla llegábase a la despensa. La había visitado hasta el botalón, hasta los límites del tajamar y tampoco allí podría haber nada más. Debajo había encontrado ya las jarcias y la colección de fósiles. Mas allá no se podía ir.

Se volvía por tanto hacia atrás y se atravesaba toda el entrepuente con la pajarera y el vergel (...). Debajo de la caña y el timón estaban el órgano y los relojes. Y también allí se llegaba a tocar el casco. Bajando había encontrado la parte más amplia de la bodega, con los demás menesteres, el lastre, la madera; ya había golpeado contra el forro para controlar que no hubiera ningún falso fondo que diera un sonido hueco. (...) En la popa, más o menos debajo del órgano, estaban el tabuco con la palangana, el telescopio y los demás instrumentos. Al examinarlo, reflexionaba, no había controlado si el espacio terminaba justo al lado del timón; por el dibujo que estaba haciendo le parecía que la hoja no le permitía imaginar otro hueco, si había dibujado bien la curva de la popa. Debajo quedaba sólo el chiribitil subterráneo y de que allende aquél no hubiera nada más estaba seguro (LIDDA, pp. 194-195).

Inseguro de su lectura Roberto volverá a la tarea: esta vez realiza otro trazado del navío visto desde arriba, para controlar la anchura de la nave en relación a la altura ya establecida en el dibujo longitudinal anterior. Es así como descubre finalmente el escondrijo secreto del padre Caspar Wanderdrosel:

¿Había otros tabucos? Volvió a hacer el dibujo e intentó representar el navio no como si lo viera de lado, sino como si lo mirara desde lo alto de la gavia. $Y$ decidió que en la colmena que iba imaginándose podía caber aún un agujero debajo del compartimiento del órgano, del cual pudiera descenderse ulteriormente sin escalera al chiribil subterráneo. No lo suficiente como para contener todo lo que faltaba, pero en cualquier caso un escondrijo más. Si en el techo de chiribitil ciego existía un pasaje, un agujero por el cual izarse a aquel novísimo espacio, desde allí podía subirse a los relojes y desde allí recorrer todo el buque. Roberto estaba seguro de que el enemigo no podía estar sino allí (LIDDA, p. 196).

El espacio tópico está completamente «cartografiado» y el largo proceso de reconocimiento semiótico ha concluido en lo que respecta a ese tránsito entre el significado textual de una plataforma de visión y de observación del espacio heterotópico circundante hacia la configuración de un cronotopo mu- 
cho más nítido y definido cuyos rasgos permiten establecer relaciones de sentido con las anteriores tramas novelescas de Eco y con un amplio espacio de género (Bajtín, 1989: 237-250). Roberto volverá a efectuar exploraciones internas, pero lo que aún quedaba en el navío de desconocido, de probable o misterioso ya no existe como tal. Roberto es ahora el actor y figura del $h a-$ bitante de ese espacio tópico y paradójico que aúna el máximo confinamiento con el máximo poder panorámico, una de las constantes tópicas y espaciales de todas las novelas de Eco y que denominamos como la obsesión del oxymoron o el trazado casi permanente de la dinámica de los contrarios a partir y sobre la cual los personajes (nivel del relato) o los narradores (nivel del discurso) ejercen el trabajo semiótico. Nos interesa ahora, para configurar el itinerario espacial de L'Isola del giorno prima, la lectura semiótica de las últimas fases narrativas. Roberto De La Grive a bordo del Daphne cumple, como hemos señalado, una suerte de proceso de transfiguración y transubstanciación.

\section{EL ARTE DE LA FUGA O LA SEMIOSIS ILIMITADA: EL ME- RIDIANO SALOMÓNICO DE CASPAR WANDERDROSEL}

El cuerpo se habría vaciado de toda su savia, sangre, bilis o pituita. El agua, entrando por todos los poros, penetrando en las orejas, le habría revocado el cerebro de sal. Le habría substituido el humor vítreo de los ojos. Le habría invadido las narices yendo a desleir todo vestigio de elemento terrestre. Al mismo tiempo los rayos solares lo habrían alimentado de partículas ígneas (...). Y él, ahora liviano y volátil, levantábase para empalmarse con los espíritus del aire, luego con los del sol (LiDDA, pp. 399-400).

El padre Caspar, una vez sacado de su escondite y luego de un mutuo reconocimiento, pondrá al tanto a Roberto del itinerario seguido por él a bordo del navío holandés perteneciente a la ilustre Vereenigde Oost Indische Compagnie: la meta era alcanzar las antípodas cruzando hacia el sureste, luego de tocar el puerto de Sancti Thomae en Nueva Guinea, pero los sorprendió una tormenta y perdieron la orientación, posiblemente pasando muy cerca, sin saberlo, de lo que ahora conocemos como Australia. Según los planes del maestro jesuita, miembro de la Curia General de la Compañía de Jesús, el objetivo final era el hallazgo de la Isla Salomónica donde pasaría el meridiano $180^{\circ}$ para instalar allí su Specola Melitense, un novísimo artefacto científico que permitiría determinar las Longitudes con precisión matemática. 
La Specola es una suerte de artefacto Kircheriano, compuesto de mecanismos y engranajes múltiples, de varios niveles de lectura y operabilidad. En palabras del mismo Wanderdrosel, un syntagma de novissimi instrumenti physici. Puede muy bien compararse con los artilugios dibujados en la obra de Athanasius Kircher (Gómez de Liaño, 2002). La Specola Melitensis, acoplamiento de un forma cúbica y de una pirámide, superpone, bajo la forma de diagramas, esquemas y dispositivos de mando, el resumen enciclopédico del saber: Medicina, Botánica, Química, Hermética, Farmacia atractiva y purgativa, los alfabetos conocidos del mundo, el theatrum cosmographicum, la mónada hieroglífica y la lengua adámica. Caspar compara metafóricamente la Specola con un megahorologium universal, un speculum cosmigraphicum, compendio máximo del saber. Un símil objetual de aquel anfiteatro de la sabiduría de Khunrath (Roob, 1997) y que conforma un sistema y paradigma con toda la constelación de artefactos y artilugios semióticos de la sinécdoque y la metáfora que pueblan también todas las novelas de Eco. El padre Wanderdrosel aseguraba que esa era la Isla tan buscada. Al llegar a la bahía la Specola fue desembarcada e instalada en uno de los promontorios (el promontorio norte) al igual que otros bastimentos y materiales. Pero una serie de sucesos trágicos e imprevistos impidieron que la labor se llevase a cabo. La tripulación, creyendo que Caspar estuviese contagiado de peste, abandonó el Daphne y fue víctima de las emboscadas de los aborígenes de la Isla. Ahora, para demostrar su hipótesis, intentaba alcanzar la Isla. Según Wanderdrosel, profundo erudito en el significado numerológico del Templo de Salomón, la Isla debía corresponder sin duda al cruce del meridiano $180^{\circ}$ con el paralelo que divide el globo en dos partes iguales. El narrador-transcriptor nos propone la hipótesis de que en realidad, sin saberlo, el Daphne había tocado fondo en la bahía de una de las islas Fiji, para ser más exacto: en la isla de Taveuni, donde pasa efectivamente no el salomónico y divino meridiano $180^{\circ}$ sino la línea imaginaria de nuestro actual meridiano de Greenwich (LIDDA, p. 212 y Sobel, 1999).

La lógica del discurso del padre Wanderdrosel, trazada sobre el decurso del relato bíblico del Diluvio Universal y de la Creación del Mundo, coloca a la Isla como el lugar terrestre que señala la justa separación entre el día de antes (el más allá y hacia adelante de la Isla) y el día del después (el espacio que se abre a partir del Daphne varado en la bahía). Sigue siendo, piensa Roberto, la idea de un Punto Fijo, pero revestido ahora simbólicamente de otros significados y que remite, desde luego, a la búsqueda análoga del «punto fijo» de aquel mapa secreto e imposible que, colocado bajo el ritmo implacable del Péndulo de León Focault, debería de haber indicado el sitio 
exacto para acceder al control de todas las corrientes telúricas del mundo y del universo.

La Specola Melitensis, abandonada por él, la Isla jamás será alcanzada. El dulce y erudito Padre Caspar desaparecerá para siempre en el fondo del mar en uno de sus bizarros intentos por alcanzar la Isla a través de una especie de escafandra-submarino de enorme peso y dificultoso manejo. Roberto, aunque aprenderá a sumergirse y sorprenderse con la infinita variedad de peces y organismos que pueblan esas costas, tampoco podrá ser ducho en el difícil arte de nadar a contracorriente y sortear los peligrosos bancos de corales y los fuertes oleajes. La isla jamás será alcanzada y la única posibilidad (por demás aprovechada magistralmente) de Roberto De La Grive será la de apropiarse y reconocer la Isla a través de una novela, un relato de ficción interno a la ficción, en donde el espacio y los objetos y seres de la Isla del día de antes adquieren el perfil de un locus amoenus bucólico y romántico donde podrá unirse eternamente con su amada Señora. El experimento a bordo (en la zona más alta del alcázar) para determinar el meridiano de la isla con el símil mecánico de la Specola, inventado por Caspar, fracasa estrepitosamente. Mientras el padre Caspar se afana por convencer a Roberto de que pierda su miedo al mar y pueda nadar hasta la Isla, éste, combinando su competencia enciclopédica adquirida en los círculos intelectuales liberales de $\mathrm{Pa}$ rís y Casale con las enseñanzas físicas y astronómicas de Caspar, no puede ocultar su asombro y perplejidad ante las oscilaciones virtuales de esa línea imaginaria que dividiría el tiempo del mundo en dos mitades: un antes y un después de la creación.

\section{INFINITOS MUNDOS: DEL RECONOCIMIENTO A LA INVEN- CIÓN RADICAL}

Mas todas las estrellas que vemos son otros tantos soles, y cada uno está en el centro de su turbillón, y todo el universo es un gran giro de turbillones con infinitos soles e infinitísimos planetas, ;incluso allende lo que nuestro ojo ve, y cada uno con sus propios moradores! (LIDDA, p. 255).

In relato i nomi dei generi sono insifficenti perché essi sono inutili: un genere altro non é che una congiunzione di differenze... (U. Eco, Semiotica e filosofia del linguaggio, p. 102).

En un intenso debate científico con el padre Caspar, Roberto concluye para sí que el mundo natural se dispone como un perfecto y complejo artifi- 


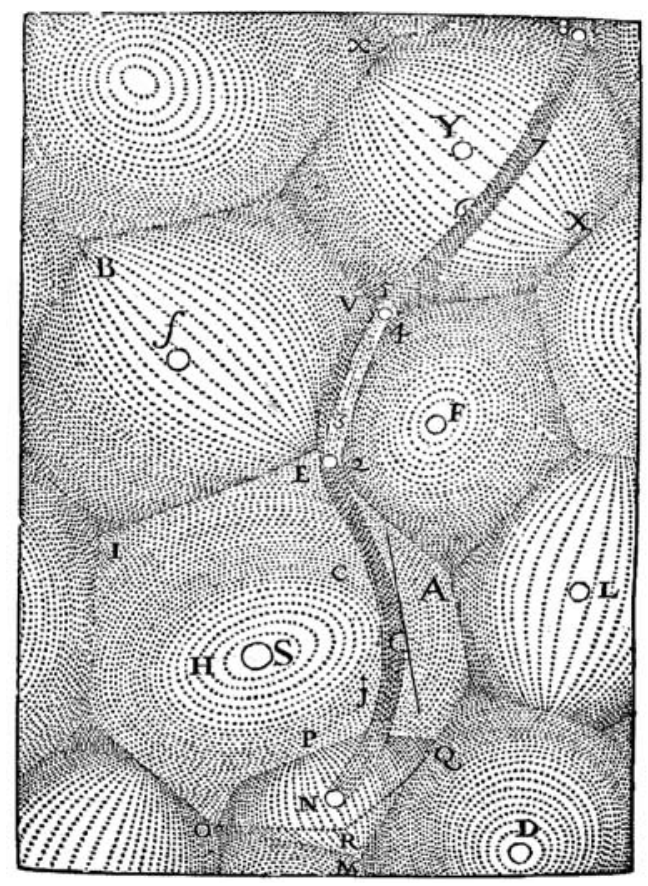

cio que oculta el mecanismo que lo produce. La metáfora del teatro, unida de hecho al uso del Cannocchiale aristotélico de Tesauro y a las teorías del emblema y la empresa, se vuelve a evocar para poder comprender el lenguaje de signos a través del cual «habla» el mundo, el universo. Luego de citar, casi directamente la teoría de los torbellinos de Descartes donde los vórtices de materia provocan el movimiento celeste y todos los demás movimientos, Roberto, contemplando la Isla desde el navío y las estrellas a través de su $\mathrm{Hi}$ pérbole de los ojos, insistirá en ese particular espectáculo del universo y sus propiedades mecánicas:

Desde nuestro asiento, nosotros no vemos el teatro como realmente es: las escenas y las máquinas han sido predispuestas para conseguir un buen efecto de lejos, mientras las ruedas y los contrapesos que producen los movimientos han sido ocultados a nuestra vista. Y sin embargo, si en el patio hubiere un hombre del arte, sería capaz de adivinar cómo se ha conseguido que un pájaro mecánico se levante repentinamente en vuelo. Así debería haber hecho el filósofo ante el espectáculo del universo... (LIDDA, pp. 258-259). 
La imagen del universo que Roberto se ha ido configurando es la de un espacio de múltiples perspectivas cambiantes, un espacio móvil de tourbillons, vórtices de partículas y átomos que sostienen combinaciones cuasi-infinitas. Todo el sistema parece moverse y desplazarse en un conjunto de círculos variados que se cruzan y superponen, dando la figura de un enorme engranaje mecánico de ruedas que debería girar en una suerte «de revolución inmensa que dura milenios» en el interior de otro sistema de ruedas y así sucesivamente:

En turbillones desprovistos de planetas, en turbillones que se chocan el uno contra el otro, en turbillones que no sean redondos sino hexagonales, de suerte que cada cara o lado de ellos introdúzcase otro turbillón, todos juntos componiéndose como las celdas en una colmena, o que sean polígonos, los cuales, apoyándose el uno al otro, dejen unos vacíos, que la naturaleza llena con otros turbillones menores, todos engranados entre sí como las ruedas de los relojes... (LIDDA, p. 259).

La estrategia polifónica de la novela introduce las voces de algunos filósofos y científicos del siglo XVII. En especial, como ya hemos indicado, la de Descartes. Pero al mismo tiempo también Spinoza y Leibniz. Roberto, desde su arribo al Daphne, parece ocupado fundamentalmente en la puesta en práctica de un método de autoconciencia filosófica a través de la contemplación de la naturaleza y de una mirada que progresivamente se desplaza siempre más allá de la noción de un cosmos cerrado. Es un gedankenexperiment, en el sentido literal del término: el sujeto busca en sí mismo -haciéndose eco de los elementos y nociones en boga de la filosofía de la naturaleza del siglo XVII- los principios del conocimiento, intentando otorgar una unidad más o menos organizada y sistemática al mundo observado. Roberto, aunque se siente en algunas ocasiones medianamente atraído por las retóricas de las cosmogonías al estilo del padre Caspar o el universo de las analogías y la simpatía universalis del Dr. Byrd, seguirá finalmente la ruta de la comprobación y de la hipótesis. Desde esta perspectiva, la mirada semiótica de Roberto De La Grive es la mirada interpretativa y metafórica de Galileo y de Tesauro. Del arsenal semiósico del padre Caspar, por ejemplo, valorará la idea de utilizar todos los métodos posibles, aunque parezcan falsos, con tal de determinar el origen de un fenómeno, pero, al mismo tiempo, no aceptará la visión predeterminada y hermética que cierra el camino de la semiosis ilimitada. Para el Roberto de los capítulos finales de la novela, al igual que el sujeto interpretante implícito del Trattato y sobre todo de Kant e l'ornitorrinco, no podemos sustraernos jamás a la continua pre- 
gunta que el objeto dinámico (llámase finalmente substancia, cuerpo, vacío, movimiento de partículas) nos dirige y solicita (Eco, 1997: 3-15). La comprobación experimental de Roberto parece pobre de artefactos e instrumentos complejos, que podría resumirse, por ejemplo, en el uso del aparentemente simple anteojo largavistas o del trazado «experimental» del dibujo del Daphne, e incluso a través del creciente uso de las metáforas verbales para reconocer y poder describir las novedades del mundo que lo rodea en su naufragio. El instrumento cognoscitivo de este sujeto observador-explorador es la semiosis y la metáfora. Es la consciencia del signo como convención y arbitrariedad que, a partir del siglo XVII en adelante, se complejiza y que, entre uno de sus elementos fundamentales, comprende la reflexión sobre los objetos de la percepción, los objetos del mundo. Ya a finales del siglo XVI se resquebraja y deja de ser socioculturalmente activa la indisolubilidad entre los nombres y las cosas. La prosa del mundo y la escritura de las cosas dará paso a la mathesis y las taxonomías (Foucault, 1968: 34-49). Por tanto, sobre esta plataforma semiótica, reino de taxonomías y campos enciclopédicos, sistemas de reconocimiento y metodologías experimentales sobre las cuales se construirá buena parte del discurso de la ciencia europea, se cruza y superpone el hacer de este personaje novelesco verdaderamente empeñado (hasta empecinado) en discurrir-descorrer el telón de ese gran teatro del artificio natural para poder percibir-discernir la naturaleza y consistencia semiótica del límite posible de los objetos.

Roberto De La Grive puede verse en cierta forma como un racionalista barroco que intenta conjugar los principios del empirismo y del racionalismo. En sus observaciones y reflexiones finales, antes de decidir abandonar e incendiar el Daphne, parece hacer suyas algunas tesis de un filósofo como Baruch Spinoza respecto a la existencia de una substancia única que informaría a todas las cosas singulares. Discurre sobre las formas, según las cuales se relacionan el pensamiento y el ser. Se formula de algún modo, explícita e implícitamente, las preguntas fundamentales que se hacía la filosofía del siglo XVII: ¿Qué es eso que llamamos substancia y que debería mantenerse a pesar del cambio de los fenómenos, ese algo que está detrás de todos ellos?, ¿No podemos decir nada sobre eso que denominamos substancia? ¿Sólo existen mis percepciones concretas? ¿Qué hay detrás de todo este gran artificio de relojería, este gran teatro del mundo del cual no vemos los mecanismos que lo hacen posible a los sentidos? Pero si referimos el mundo doxástico-epistémico de Roberto al entorno conceptual de Kant e l'ornitorinco, veremos de qué forma el protagonista pone en escena, en el marco de la ficción narrativa y novelesca y conjuntamente a los problemas fi- 
losóficos indicados, el funcionamiento del modelo triadico de Peirce y más específicamente lo relacionado con el problema teórico de la noción del objeto dinámico (Vicente Gómez, 1998). Roberto enuncia en un momento de la novela la posibilidad de ser partícipe de ese momento pre-semiótico donde las cosas son nombradas por primera vez y donde el sujeto, como náufrago renacido en una Isla virginal, tiene la suerte de percibir casi directamente esa consistencia y el secreto de la transformación de la substancia que informa el mundo. Remitiendo este proceso figurado del protagonista al modelo sígnico de Charles Sanders Peirce (cf. al respecto el número monográfico Ch. S. Peirce y la literatura, Signa 1, 1992, coordinado por José Romera Castillo), se trata de la posibilidad de la alternativa imaginaria de la ficción por instalarse en el principio de la génesis de una cadena de interpretantes. Incluso, para ser más precisos, en el hipotético momento en el cual un sujeto interpretante debe inventar, obligado por la flagrancia de las substancias y sus objetos dinámicos, un signo inaugural, auroral:

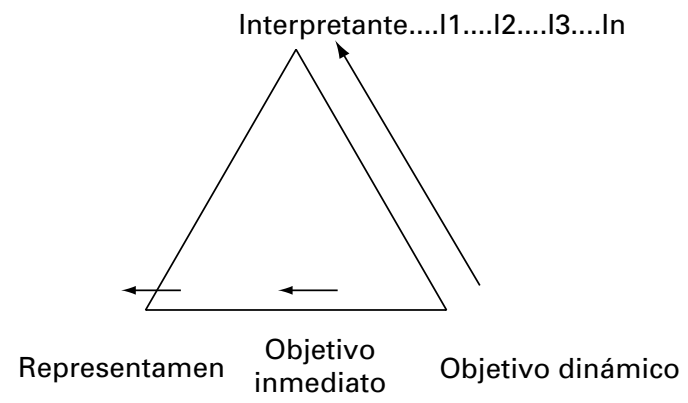

Uno de los temas fundamentales que recorre finalmente el relato de naufragio de Roberto De La Grive es el surgir de la posibilidad de inventar un nuevo lenguaje capaz de instituir una nueva relación con las cosas. Confundiendo a menudo la dimensión del tiempo y del espacio, Roberto se plantea la posibilidad de experimentar una condición adámica:

Si la Isla se erguía en el pasado, era el lugar que él tenía que alcanzar a toda costa. En aquel tiempo fuera de los goznes, él tenía no que encontrar sino inventar de nuevo, la condición del primer hombre. Demora no de una fuente de la eterna juventud, sino fuente ella misma, la Isla podía ser el lugar donde cualquier criatura humana, olvidando el propio ser emponzoñado, habría encontrado, como un niño abandonado en la selva, un nuevo lenguaje capaz 
de nacer de un nuevo contacto con las cosas. Y con él habría nacido la única y verdadera nueva ciencia, de la experiencia directa de la naturaleza, sin que filosofía alguna la adulterara (como si la Isla no fuera padre que transmite al hijo las palabras de la Ley, sino madre que le enseña a balbucear los primeros nombres) (LIDDA, p. 293).

El sujeto enuncia los elementos de una teoría del conocimiento, basada en la experiencia directa con los fenómenos sin intervención alguna de instrumentos o signos de intermediación y traducción. Se trata de un escenario de la experiencia adámica: un universo de cosas y acontecimientos, aún no codificado por lenguaje alguno. Para descubrir realmente las leyes que gobiernan el movimiento y la apariencia de las cosas en su devenir, se hace necesario intentar ir más allá de las metáforas en una suerte de captura del movimiento de la substancia in nuce:

Sólo así un náufrago renacido habría podido descubrir los dictámenes que gobiernan el curso de los cuerpos celestes y el sentido de los acrósticos que éstos trazan en el cielo (...). Sólo por la nariz que sangra, a causa de la caída de una fruta, habría aprendido verdaderamente de un golpe tanto las leyes que arrastran los graves a gravedad, como de motu cordis et sanguinus in animalibus (...). Y quizá habría podido entender por qué la tierra es un espejo opaco que pincela con tinta lo que refleja, el agua una pared que vuelve diáfanas las sombras que se imprimen en ella, mientras en el aire, las imágenes no encuentran jamás una superficie de la cual rebotar y la penetran huyendo hasta los extremos límites del éter... (LIDDA, p. 294).

No es que el protagonista abjure del signo y la semiosis como medio de conocimiento: Roberto De La Grive en ningún momento rechaza el uso semiósico del anteojo largavistas y por tanto del acto primario de nominación, de asignación de un nombre a las cosas. De La Grive continúa siendo la figura novelesca que reconfirma la estrategia del Nomos y no de la Physis.

Se propone más bien construir imaginariamente un escenario límite y de naturaleza proto-semiótica, a partir del cual se pueda inventar un primer conjunto o repertorio de signos más allá de la metáfora que, en este momento del relato, le parece ya insuficiente como método sígnico para penetrar en la esencialidad de los fenómenos. Pero queremos señalar que esta esencialidad no es remisible a un plan cosmogónico, sino más bien a la imagen moderna del sujeto curioso y filósofo amateur, apasionado por la posibilidad de ser el actor principal de un acto de invención sígnica $\mathrm{y}$, por tanto, de un contacto directo con el instante o proceso temporal, en el cual los objetos dinámicos (en el mismo sentido de Peirce y de Eco) «emanan» el signo pro- 
piamente dicho. El texto novelesco prefigura un escenario pre-semiótico donde el sujeto interpretante, convertido en nomoteta y deslastrado del filtraje de un saber filológico, sea capaz de «aprender a balculcear los primeros nombres». En este sentido L'Isola del giorno prima es, en buena medida, un relato sobre esa delgada frontera semiótica que separa el momento del interpretante emotivo y del interpretante dinámico, el feeling del signo y la percepción de un espécimen propiamente dicho.

El sujeto no abjura de la Enciclopedia e instituye de facto la posibilidad de trazar un espacio y un recorrido enciclopédico original. Roberto De La Grive se inscribe de lleno en una semiosis de la nominación y del reconocimiento del mundo. Al mismo tiempo, es un sujeto que reconoce, proclama y acepta la transformabilidad y mutabilidad del mundo, un universo cambiante que, aunque regido hipotéticamente por una única substancia, permite sin embargo (y como un mecanismo fundamental irrenunciable) que las cosas pueden manifestarse en múltiples modos, incluso opuestos y contradictorios. Es esta multiplicidad y transformabilidad el motivo principal de su asombro y curiosidad:

La Lógica de Roberto no era la de aquellos filósofos cultipicaños y bobicultos, intrusos en el atrio del Liceo, que querían siempre que una cosa si es de tal modo no pueda ser también del modo opuesto (...). Descubrir las leyes del Universo a través de un anteojo le parecía solamente la forma más larga de alcanzar una verdad que habríasele revelado en la luz ensordecedora del placer si hubiera podido abandonar la cabeza en el regazo de su amada (LIDDA, p. 294).

Siguiendo el cuadro de los Modos de producción sígnica del Trattato (Eco, 1981: 361) el texto figurativiza el tránsito y superposición del reconocimiento a la invención. De La Grive piensa ahora que no dispone enciclopédicamente de verdaderos types que puedan dar cuenta de los tokens o réplicas de ese nuevo mundo percibido y, aun sin abandonar la función cognoscitiva de la metáfora, imagina la alternativa de una suerte de invención radical capaz de instituir un código en el cual «algo es transformado por alguna otra cosa que todavía no está definida» (Eco, 1981: 400-406). Es el espacio de las invenciones regidas por ratio difficilis, dependientes de modelos de contenido toposensibles. La isla del día de antes y su entorno de cosas y fenómenos podría ser vista como ese escenario donde los especímenes están allí esperando un correspondiente modelo perceptivo, instituido por el sujeto de la semiosis:

...el caso de la invenciones radicales es algo diferente ya que el emisor prácticamente se salta el modelo perceptivo y excava directamente en el continuum informe,configurando el precepto en el momento mismo en que lo transforma en expresión (Eco, 1981: 403-404). 


\section{RECONOCIMIENTO DEL MUNDO MARINO: PECES Y METÁ- FORAS}
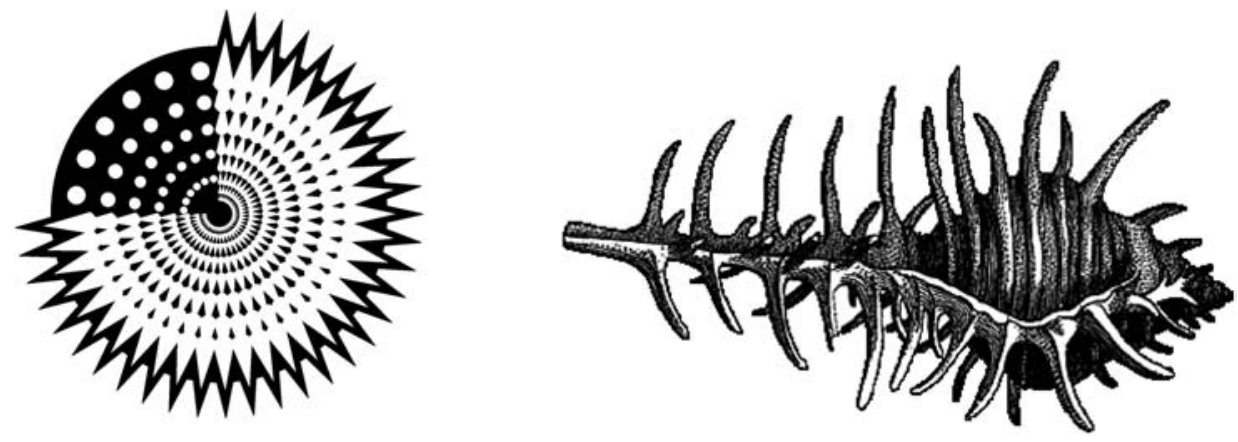

$Y$ apenas ayer ¿habría podido sospechar que bajo el mar, no en un planeta lejano o en una gota de agua, sino en una parte de nuestro mismo universo, existiera Otro Mundo? (LIDDA, p. 341).

...la metáfora verbale richiede spesso per essere in qualche modo spiegata nelle sue origini, il rinvio o esperienze visive, auditive, tattili, olfative (U. Eco, Semiotica e filosofia del linguaggio, p. 143).

En los capítulos 32, 33 y 34 De La Grive se sumerge y explora el espacio marino. Se desplaza provisto de una primitiva máscara de submarinismo, atónito ante la riqueza y variedad de especies y organismos animales, vegetales y minerales. Su capacidad descriptiva es puesta en crisis ante la no disponibilidad de términos y categorías nuevas o suficientes para nombrar y reconocer lo que se exhibe y muestra ante sus ojos. La fuerza semiósica del objeto le seduce e induce a describir. La visión de los corales, seres jamás vistos hasta ese momento, es precedida por una fase de ajuste perceptivo. La máscara submarina funciona como una prótesis que, una vez ajustada, le permitirá ver con mayor nitidez lo que anteriormente eran sólo manchas y el texto dispone de un proceso casi puntual e instantáneo que se impone en el campo visual del sujeto explorador, a la manera de una escena teatral sorpresiva, y al mismo tiempo ofrece una localización espacial en términos de un espacio profundo y vertical, cuya magnitud puede preverse, pero que queda literalmente fuera del campo visual.

En este nuevo escenario submarino el sujeto descriptor recurre a un efecto de enumeración metaforizada (recurrente en el estilo novelesco de Eco), el universo enciclopédico de las telas y brocados de la época funcionará como 
interpretante para nombrar y apropiarse cognitiva y pasionalmente del entorno. A través de este sistema previo de nomenclatura el texto despliega y expande la partonimia inicial en esa estrategia de listado y enumeración cuyo uso es frecuente en las novelas de Eco (Hamon, 1981: 140-142):

Durante un trecho vio sólo manchas, luego, como quien llega en navío, en una noche de niebla, ante el acantilado, que de repente se perfila a pique ante el navegante, vio el borde del abismo sobre el que estaba nadando.

Quítose la máscara, vacíola, volviósela a colocar, sujetándola con las manos y con lentos golpes de pie fue al encuentro del espectáculo que había vislumbrado apenas.

¡Aquellos eran los corales! Su primera impresión fue, a juzgar por sus notas, confusa y atónita. Hízose la impresión de encontrarse en la tienda de un mercader de telas, que adereza ante sus ojos cendales y tafetanes, brocados, rasos, damascos, terciopelos y flecos, borlas y cárieles, y luego estofas, capas pluviales, casullas, dalmáticas. Pero las telas movíanse con vida propia con la sensualidad de bailarinas orientales... (LIDDA, pp. 327-328).

El texto subraya más que en ninguna otra parte la carencia o insuficiencia de modelos perceptivos de referencia. Roberto, más allá de la posibilidad ahora cada vez más dificultosa de construir cadenas de metáforas y de analogías, intenta arriesgadas descripciones y en esta operación, sin proponérselo explícitamente, nos da (o se da) a ver el mundo, como si fuese por primera $v e z$, en un bricolage de signos y residuos de otros campos discursivos. La acumulación y superposición heteróclita de referentes crea un efecto análogo a las figuras del pintor Archimboldo, rostros y objetos poco conocidos, configurados a partir de frutas y vegetales, de objetos y artefactos conocidos:

En aquel paisaje que Roberto no sabe describir porque lo ve por primera vez y no encuentra en la memoria imágenes para poderlo traducir en palabras (...). Había peces rayados con más colores, cuáles a lo largo, cuáles a lo ancho, cuáles al través y otros aún a ondas, había unos labrados de taracea con migajas, de manchas caprichosamente ordenadas, unos granados o moteados, otros remendados, apedreados y minudísimamente punteados, o recorridos por vetas como los mármoles.

Otros aún con dibujo de serpentinas, o trenzados con más cadenas. Los había cuajados de esmaltes, diseminados de escudos y rosetas. $Y$ uno, bellísimo entre todos, que parecía completamente envuelto por cordoncillos que formaban dos filas de uva y leche (...). Roberto identificaba cepas de plátanos, cestas de hogazas de pan, canastos de nísperos broncíneos sobre los que pasaban canarios y lagartos verdes y colibríes... (LIDDA, p. 328). 
Los objetos descritos por Roberto se asemejan a quimeras compuestas con materiales, detalles y formas procedentes de su mundo de la experiencia. Pero los «viejos componentes», a través de los cuales debe construir el nuevo percepto y poder reconocerlo como signo, poseen diversas magnitudes y escalas, en donde no existe una relación de conformidad y proporcionalidad entre la forma del contenido y la forma de la expresión: un elemento «pequeño» a nivel expresivo puede significar «grandes» unidades a nivel del contenido o viceversa. Es un ejemplo de construcción radical de un lenguaje semisimbólico en el mismo sentido de Hlejmslev:

Lo que veía ahora no era un pez, mas ni siquiera una hoja, sin duda era algo vivo, como dos anchas rebanadas de materia albicante, bordadas de carmesí, y un abanico de plumas; y allá donde nos habríamos esperado los ojos, dos cuernos de lacre agitado... (LIDDA, p. 329).

Roberto sustrae un trozo de coral para llevárselo a bordo del Daphne y admirarlo con detenimiento (LiDDA, cap. 34, p. 340). Un «sosía de una piedra», como señala en sus notas, que en principio le recordó la calavera de su último sabio docens y amigo, el padre Caspar Wanderdrosel, que con toda seguridad debe estar ahora reposando en el fondo del mar transformado en coral o alga marina. Este trozo del mundo submarino, con su novedosa y particular morfología, sus simetrías dinámicas y recombinaciones ad-infinitum de un motivo poliédrico, suscita en Roberto la continuación de una intensa reflexión sobre la estructura de la materia y la teoría de los infinitos mundos que se entrelazan y suceden gradualmente en el juego de las substancias entre el microcosmos y el macrocosmos. Uno de los esquemas que el sujeto emplea para describir el coral recuerda el dibujo de los tourbillons de René Descartes a través del cual explicaba su teoría de los cuasi-infinitos vórtices de partículas o átomos que conforman finalmente el orden del mundo. Aquí, como en otros momentos anteriores de la novela, la mirada se vuelve microscópica y penetra en los intersticios y micromorfismos de los objetos:

No parecía una calavera. Era más bien una colmena mineral compuesta de polígonos irregulares, pero los polígonos no eran las unidades elementales de aquel tejido: cada polígono mostraba en su mismo centro una simetría irradiante de hilos finísimos entre los cuales aparecían, si se aguzaba la vista, resquicios que quizá formaban otros polígonos y, si el ojo hubiese podido penetrar aún más allá, habría divisado a lo mejor, que los lados de aquellos pequeños polígonos estaban formados a su vez por otros polígonos más pequeños aún, hasta que, dividiendo las partes en partes, hubiera llegado el mo- 
mento en el que habríase detenido ante aquellas partes no seccionables ulteriormente, que son los átomos... (LIDDA, p. 340).

Más adelante, cuando Roberto pierde ya casi toda esperanza de alcanzar físicamente la Isla (pudiendo solamente imaginársela como una suerte de locus amoenus de su novela escrita a bordo del Daphne) volverá a ejercer una reflexión final sobre la arquitectura del coral y sobre la delgada frontera que debería separar los organismos vivos de los no-vivos:

Si el coral era cosa viva, díjose, era el único ser verdaderamente pensante en tanto desorden de cualquier otro pensamiento. No podía sino pensar en la propia ordenada complejidad, de la cual, no obstante sabía todo, y sin la espera de imprevistos desbarates de la propia arquitectura (...). En todos los objetos debe mantenerse un movimiento continuo vertiginoso en los vientos, fluido y regulado en los cuerpos animales, lento pero inexorable en los vegetales, y sin duda más lento, pero no ausente en los minerales. También aquel coral, muerto para la vida coralina, gozaba de un propio agitarse subterráneo, propio de una piedra (LIDDA, p. 376).

\section{TRANSUBSTANCIACIONES: EL ÚLTIMO VIAJE}

Entonces ambos habrían continuado su viaje en el presente, derechos hacia el astro que los esperaba, polvo de átomos entre otros corpúsculos del cosmos, vórtice entre los vórtices, eternos y a como el mundo porque ribeteados de vacío. Conciliados con su destino, porque el movimiento de la tierra trae terrores y daños, pero la trepidación de las esferas es inocente (LIDDA, p. 400).

...l' uomo e i segni esterni sono identici, nello stesso senso in cui sono identiche le parole homo e man. Quindi il mio linguaggio é la Orma globale di me stesso: perché l' uomo é il pensiero (Ch. S. Peirce, Collected Papers, 5.313314 , cit. Trattato di semiotica generale, U. Eco, p. 378).

Extasiado en la idea de un universo sin límites, y sin embargo ordenado en su complejidad aparentemente caótica y heterogénea, Roberto De La Grive dispone, gradualmente y en forma de indicios más o menos evidentes, una fase narrativa de disolución y transubstanciación material y orgánica. Reflexiona sobre Dios y el Azar como dos posibles actores de un mismo universo: de un universo de universos en continua transformación. Si nos atenemos a algunas sugerencias teóricas planteadas en algunos ámbitos de estudio, el protagonista de La isla del día de antes constituye la figura ficcional neta y sin residuos del sujeto curioso que, siendo casi siempre una suerte de 
filósofo amateur, escudriña asombrado el mundo y las cosas, tratando de descubrir el movimiento y la esencia interior que los anima (Raimondi, 2002: 23-30, 75-80 y Blumemberg, 1984: 105-107). Pareciera efectivamente un gran gedankenexperiment alrededor de un género literario, producto del siglo XVII, en el cual arte y ciencia se entrelazan en un discurso sobre los objetos y los fenómenos poblados de referentes, procedentes de la filosofía natural y de la naciente enciclopedia de la ciencia moderna animada por Bacon, Leibniz, Descartes y luego por Newton. Es, como apuntamos, precisamente la metáfora y su símil icónico-objetual el anteojo largavistas, la figura textual prominente de este tipo de discurso. Si nos fijamos, Roberto se imagina, cual nomoteta, bautizando los lugares y cosas de su enigmática Isla, escenario de una semiosis in nuce, abandonando incluso el ya probado poder de la metáfora. Pero no lo logra.

El texto nos dice implícitamente que esa mirada virginal es ya casi imposible. La Isla no se alcanza, sino que permanece hasta el final como el probable escenario de una aventura dentro de la aventura: el desenlace novelesco y romántico de un amor soñado e imposible entre Roberto y su amadísima Señora y paralelamente la imposibilidad de acceder plenamente y sin mediación semiótica a un escenario de objetos «nunca vistos». A bordo del Daphne, en el combés, Roberto reúne su pequeño muestrario de especímenes marinos, mirándolos como si fuesen metáforas y metonimias de un universo aún enigmático. ¿Cuántos mundos pueden tener cabida en una cosa muerta?:

Para ver si y cuantos mundos pueden tener cabida en una cosa muerta, Roberto había ido al pequeño museo del Daphne y había alineado en el puente, ante sí como tantos astrágalos, todas las cosas muertas que había encontrado, fósiles, guijarros, raspas; movía el ojo de la una a la otra, sin dejar de reflexionar a trochemoche sobre el Azar y sobre los azares.

¿Quién me dice (decía) que Dios tiende al límite, si la experiencia me revela continuamente otros y nuevos mundos, ya sea arriba ya sea abajo?Podría entonces darse que no Dios sino el mundo sea eterno e infinito y siempre así sea, en un infinito recomponerse de sus átomos infinitos en un vacío infinito, según algunas leyes que aún ignoro... (LIDDA, p. 344).

En su reflexión sobre tres nociones fundamentales en el pensamiento filosófico europeo de los siglos XVII y XVIII, el espacio, el tiempo y el vacío, imagina la posibilidad de múltiples mundos, donde las leyes y relaciones cambian, pudiendo existir, por ejemplo, un universo como la Isla del día de antes, donde las unidades de «medida» espaciotemporales son diversas, donde, por ejemplo, las estrellas, los planetas o los organismos nacen y 
mueren en un instante casi imperceptible, o universos donde el tiempo era ayer. Se coloca ante la posibilidad de haber ya accedido a uno de esos mundos donde «un átomo había ya empezado a corroer la corteza de un coral muerto» (LIDDA, p. 348). La figura de ese filósofo diletante-amateur (la cual, por cierto, corresponde históricamente y sin menosprecio alguno a la de ilustres pensadores como Descartes y Hume) es acotada explícitamente por el texto. El narrador-transcriptor heterodiégetico nos lo dice con una exquisita ironía cuyo sentido, sólo en la superficie del enunciado, parece contradecir la profundidad del discurso hermenéutico del protagonista:

A tantas tales reflexiones encontrábase impelido un joven gentilhombre que desde hacía poco había descubierto los corales...Y quien sabe donde habría llegado si hubiera tenido el espíritu de un verdadero filósofo. Pero Roberto filósofo no era, sino amante infeliz recién emergido de un viaje, a fin de cuentas no coronado aún por el éxito. Hacia una Isla que le esquivaba entre las álgidas brumas del día de antes (LIDDA, p. 348).

La Isla es prefigurada como el signo y el emblema o la metáfora que le señala la noción universal y abstracta de un espacio donde el tiempo se sostiene en un infinito futuro. Sobreimponiendo en su movimiento cooperativo los interpretantes cosmogónicos (al estilo del Padre Wanderdrosel o de las utopías herméticas de la época) con los interpretantes que derivan del texto de la ciencia natural más avanzada (como en Descartes y Leibiniz o Spinoza, por ejemplo), Roberto se describirá novelescamente a sí mismo flotando eternamente a lo largo de ese eje espacial imaginario donde se separa el tiempo del ayer y el del ahora. En una nueva y última aventura de exploración hacia los arrecifes coralinos es herido por un extraño pez piedra y de nuevo a bordo del Daphne, entre delirios y sueños, continuará construyendo el final de su novela auxiliado por el fantasma del Padre Caspar. La fase de transformación y disolución del cuerpo es anunciada por el mismo protagonista en lo que el narrador denomina un ejercicio de la buena muerte:

Tendré que esperar poco, murmuraba como en una oración. De aquí a no muchos días mi cuerpo, ahora bien compuesto, habiendo cambiado de color, se volverá descolorido como un garbanzo, a continuación se tiznará todo de la cabeza a los pies y lo revestirá un color lóbrego. Entonces empezará a entumecerse y sobre esa hinchazón nacerá una hedionda calumbre. Ni mucho hará falta para que el vientre empiece a dar un estallido (...). En este fango se generará luego una gran cantidad de pequeñas moscas y de otros animalillos que se agazaparán en mi sangre y me devorarán pedazo a pedazo (...). Y esto mientras el Daphne se convierte poco a poco en el reino de los pájaros y si- 
mientes llegadas de la Isla harán crecer en él bestias vegetales, cuyas raíces habrán nutrido mis licores, ya arraigadas en la sentina. Por fin, cuando toda mi fábrica corporal haya sido reducida a puro esqueleto, en el curso de los meses y de los años —o quizás de los milenios_también ese andamio, lentamente se convertirá en polvorulencia de átomos, sobre la cual los seres vivos caminarán sin comprender que todo el globo de la tierra, sus mares, sus desiertos, sus selvas y sus valles, no son sino un viviente cementerio... (LIDDA, p. 372).

Se convence de que su travesía y su arribo al Daphne tenía como sentido y razón final el de proporcionarle, quizás sólo a él y a algunos otros mortales, la posibilidad envidiable de reflexionar sobre la única pregunta que nos libera de todas las «aprensiones por el no-ser»: el estudio y la reflexión del ser (LIDDA, p. 374). Reconociendo que ha sido educado a mirar el mundo sólo $a$ través del anteojo de la palabra, renuncia ya definitivamente al proyecto de alcanzar la Isla. Perdida su mascarilla submarina, última prótesis visual, continúa reflexionando sobre la constitución atómica del universo y se pregunta si finalmente también las cosas (como las piedras o los corales) pueden pensar. Es la misma pregunta que se formulaba hace años con humor el autor en una de sus conferencias sobre semiótica. Roberto intenta transformarse en una piedra, ensimismarse con su principio, probar fenomenológicamente su tesis. Reflexionar sobre la posible memoria de una piedra, su conciencia del antes y el después:

Se desnudó, se tumbó con los ojos cerrados, y con los dedos en las orejas, para que no le molestara ningún ruido, como a buen seguro le acontece a la piedra, que no tiene órganos de sentido. Intentó anular todos sus recuerdos, todas las exigencias de su cuerpo humano. Si hubiera podido habría anulado la propia piel, y no pudiéndolo se ingeniaba en hacerla lo más insensible que podía. Soy una piedra, soy una piedra, se decía (...). Así pensando, Roberto exponía lentamente lados diferentes de su cuerpo a los rayos solares, rodando por la puente, hasta encontrar una zona de sombra enfriándose ligeramente como habría debido pasarle a la piedra... (LIDDA, p. 380).

De esta reflexión concluye que el alma no sobrevive al cuerpo y que son en definitiva el vacío y la extensión lo que lo piensan. Este compuesto llamado piedra o coral no es sino un accidente, en el cual el vacío y la extensión se han demorado «un abrir y cerrar de ojos, para poder luego volver a pensarse de otro modo» (LIDDA, p. 384). Roberto cree que lo único que verdaderamente existe es este continuo trabajo de transformación-generacióndisolución entre el ser y del dejar de ser de las cosas y de los compuestos 
transitorios. Cosas cuya composición está hecha de una gran Substancia del Todo. Cumplida, tal como nos señala el «entrometido narrador», esta operación semiósica con el temple de un verdadero filósofo, Roberto enuncia la fase final de transubstanciación, el último viaje hacia esa gran substancia ( $o b$ jeto dinámico que indica las líneas de tendencia de los signos) cuya metáfora no puede ser sino el espacio del mar. Esta última travesía o itinerario estático celeste coincidirá con la escritura del capítulo final de su aventurosa novela en la cual se reuniría con Lilia, su amadísima Señora: y metafóricamente también con esa línea imaginaria de la longitud cero que atraviesa la Isla del día de antes pues en la misma época, los marineros solían usar el mismo nombre para referirse a ella:

Entonces, se dijo, si es hacia el gran mar de la grande y única substancia a donde deberemos volver todos, allá abajo o allá arriba, o dondequiera que esté ella, iyo volveré a unirme idéntico a la Señora! Seremos ambos parte y todo del mismo macrocosmos. Yo seré ella, ella será yo. ¿No es éste el sentido profundo del mito de Hermafrodito? Lilia y yo en un solo cuerpo y un solo pensamiento... (LIDDA, p. 384).

En una última evaluación de la situación topográfica y de las relaciones espaciales y de distancia entre el Navío y la Isla, el sujeto se abandona a variados cálculos de accesibilidad, a través de otras rutas que no implicaran atravesar de la insuperable barrera de corales. Desecha todas las posibilidades incluso desdeñando su misma actitud de «burgués calculador» que quiere racionalizarlo todo con medidas y cálculos geométricos, en vez de enfrentar y aceptar dignamente el noble designio que, de algún modo, el Azar le ha deparado. El único cálculo que había que realizar era el sublime cálculo del abandono del Daphne. Aquella debía ser, sin duda, la Isla de Salomón, la misma descubierta años atrás por Mendaña:

Por lo que recordaba de los mapas, ninguna otra tierra que no fuera la isla de Salomón, podía extenderse en aquella longitud, por lo menos hasta que ésta, en el Polo, no empalmara con todas las demás. Pues si un navio empleaba meses y meses y meses en realizar un recorrido igual al que habría emprendido, ¿cuánto habría durado él? Quizás años, antes de llegar al lugar donde no sabría qué había sido del día y de la noche... (LIDDA, p. 399).

El texto describe un último programa de movimientos y gestos del protagonista. Cumplidos bajo el carácter de un ritual y de acto obligatorio al mismo tiempo, Roberto se impone y dispone una secuencia encadenada de acciones hasta alejarse para siempre del Daphne, desnudo y sin amarras. An- 
tes que nada, escribe en sus papeles de notas las últimas acciones que cumplirá a bordo y para los demás, según la voz del narrador, lo que nos deja adivinar gestos, tiempos, cadencias.

Arranca el tablero en ajedrez que separa el puente de los entrepuentes. Desciende y libera los animales de las jaulas. Luego lanza al mar todos los relojes, «borrando el tiempo y para propiciarse un viaje contra el tiempo» reúne bajo el árbol mayor todos los maderos y objetos posibles para levantar una gran hoguera. Finalmente, desnudo, había bajado a la mar alejándose para siempre:

Se había levantado una nueva primera llamarada, que acarició sin tardanza las velas y las jarcias. Cuando hubo obtenido la certeza de que la hoguera estaba alimentándose por fuerza propia, se dispuso al adiós.

Estaba aún desnudo, desde que había empezado a morir transformándose en piedra. Desnudo incluso de la amarra que ya no limitaría su viaje, había bajado al mar.

Había apuntado los pies contra la madera, dándose un golpe hacia delante para apartarse del Daphne (...). Allá abajo, por encima de la línea trazada por las copas de los árboles, con ojos ya agudísimos, debería haber visto alzarse en vuelo, como una saeta que quisiera herir el sol, la Paloma Naranjada (LIDDA, p. 401).

\section{ORGANIZACIÓN DEL ESPACIO Y MODOS DE PRODUCCIÓN SÍGNICA: DE LA FOTOFOBIA A LA NITIDEZ}

Una delle prove consuete contro l'interpretabilitá dei colori é che essi non possano essere interpretati peri i non vedenti. Basta accordarsi su ció che si intende per iterpretazione: in termini perciani un interpretante é ció che mi fa sapere qualcosa di piú sull'oggetto espresso dal nome, ma non necesariamente mi fá sapere tutto quello che mi dicono altri interpretanti (U. Eco, Kant e l'ornitorrinco, p. 131).

En L'Isola del giorno prima, los referentes espaciales arquitectónicos y objetuales son fundamentales tanto para formarse una imagen retrospectiva del trabajo del tramado del texto ficcional previo a su organización final, como para la configuración misma del proceso de cooperación interpretati$v a$ del lector, es decir, tanto a nivel de lo que el mismo Eco denomina la intentio auctoris como la intentio textualis. Los signos y componentes espaciales de la narración se distribuyen en diferentes y simultáneos niveles 
funcionales del relato, pero diremos que se constituyen en verdaderos escenarios para el desarrollo de las funciones y de las acciones (Barthes, 1966). Si extendemos la noción de actor y de actante a la del objeto informador, como de hecho también proponemos en un modelo de localización espacial, podemos ver al espacio representado y organizado en el texto como un componente textual tanto a nivel funcional, accional y narrativo y no solamente como fondo que referencializa la acción de un protagonista o que sirve de escenografía para las descripciones que se despliegan en el acto narrativo (Mangieri, 1994: 47-67):

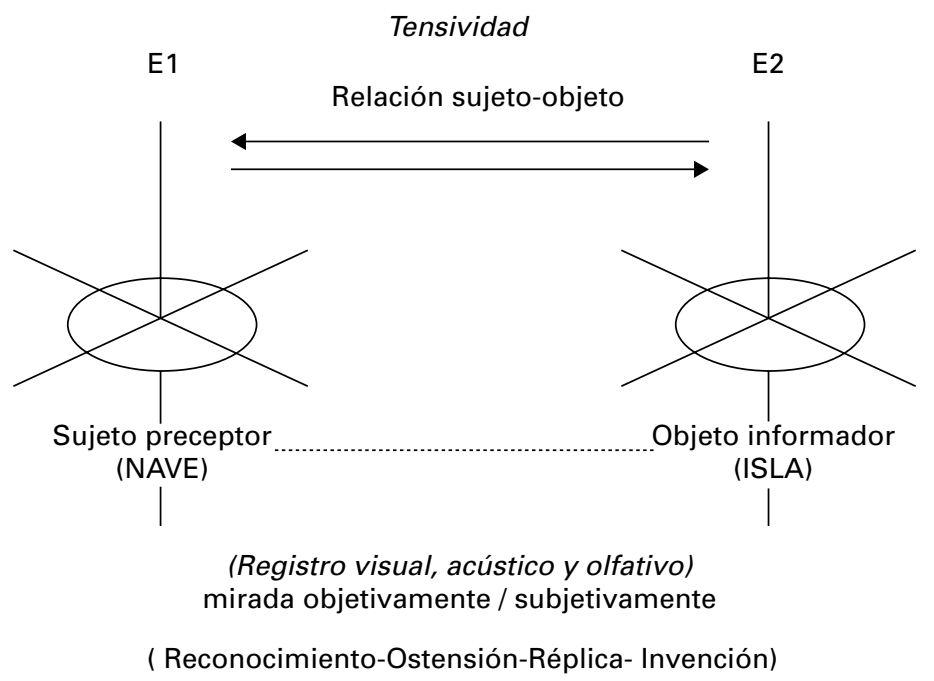

Entre la nave, hogar temporal de Roberto, y la isla (espacio heterotópico y utópico) la novela traza y dibuja la red de signos e interpretantes que oscila entre el reconocimiento, la ostensión, la réplica y la invención de las metáforas. El personaje, a través de su trabajo semiótico (pasional y cognitivo a la vez), dialoga e interactúa con los objetos y espacios en continuas relaciones de tensividad espacial y temporal. El personaje transita del reconocimiento a la invención del mismo modo que construye su mirada objetivante o subjetivante (Geninasca, 1984). Desde otra perspectiva, que reconfirma la anterior, el texto novelesco de Eco dispone con énfasis del diseño casi arquitectónico de un verdadero cronotopo en el mismo sentido propuesto por Mijail Bajtín, es decir, la construcción y organización textual de un locus en 
el cual se integran las relaciones espacio-temporales de la novela (Bajtín 1989: 237-240 y Romera Castillo, 1995). El tiempo y el espacio literario no pueden sino percibirse y «medirse» a través de un cronotopo, en este caso bajo la figura dominante y metafórica de un navío varado en la bahía de una isla del Pacífico, a través del cual:

El tiempo se condensa, se comprime, se convierte en visible desde el punto de vista artístico; y el espacio a su vez se intensifica, penetra en el movimiento del tiempo, del argumento, de la historia. Los elementos del tiempo se revelan en el espacio y el espacio es entendido y medido a través del tiempo. La intersección de las series y uniones de esos elementos constituye la característica del cronotopo artístico (Bajtín, 1989: 237).

\section{CONFINAMIENTOS Y ABDUCCIONES: OXYMORON DEL ES- PACIO}

Pero siendo la novela, si se quiere, una superposición de géneros y de invención de nuevas formas discursivas, debemos partir de la idea de que en ella se encuentran conviviendo varios cronotopos de la misma manera que ocurre desde Il nome della rosa hasta Baudolino (Eco, 2000). El texto se organiza discursivamente a partir del trabajo narrativo de alguien, que desde un espacio de la enunciación enunciada (un lugar del aquí-ahora no referenciado) y bajo la figura de un narrador-transcriptor, cuyo perfil recuerda la estrategia de la novela realista e histórica, nos comunica una historia narrada a su vez por un náufrago, gentilhombre y aprendiz de filósofo, antes soldado aguerrido, oriundo del Monferrato en Italia. El centro tópico principal de la novela es el Daphne. Es a partir de ese lugar de coordenadas imprecisas desde el cual Roberto De La Grive rememora y deja testimonio de sus aventuras, sus sueños y proyectos enciclopédicos. Es el mismo dispositivo utilizado, con variantes cronotópicas, en todas las novelas de Eco: desde un espacio generalmente reducido o confinado, aislado o semicerrado, el personaje despliega la memoria y el relato. Desde el cerramiento del espacio narrativo ejerce el trabajo abierto de la abducción y la semiosis ilimitada.

El navío, como espacio central del enunciado, es objeto de una constante y progresiva exploración y de reconocimiento semiótico hasta convertirse plenamente en una plataforma de observación y reflexión en relación al horizonte enigmático de la Isla y, desde luego, respecto al espacio heterotópico cuasi-infinito del mar y del cielo. Roberto De La Grive llega al Daphne casi ciego y afectado por una fuerte fotofobia y sólo al final el texto enuncia que 
puede ver y observar el mundo que le rodea con casi absoluta claridad y nitidez. El último microsegmento del texto no deja dudas:

Allá abajo, por encima de la línea trazada por las copas de los árboles, con ojos ya agudísimos, debería haber visto alzarse en vuelo, como una saeta que quisiera herir el sol, la Paloma Naranjada (LIDDA, p. 401).

La Isla no puede verse separada de la nave, sino que constituye su horizonte inmediato, como ocurre en Il nome della rosa con la presencia-ausente de la ciudad y la aldea. Son espacios silenciosos y apuntados como mundos posibles textuales. O en Baudolino, donde el centro tópico y cronotópico de la Torre genovesa no puede separarse de Constantinopla. Lo interesante es ver la Isla como un verdadero escenario dispuesto para ser observado, descrito e imaginado a partir de esa línea, plataforma de reconocimiento semiótico, en la cual se convierte el Daphne. Siendo así, y tratando de establecer correlaciones con la teoría semiótica, el sujeto a bordo del navío provisto de un cannocchiale galileano progresa desde el reconocimiento hasta la invención. Mostrándonos incluso la imposibilidad de una suerte de invención radical del código y, en su lugar, sirviéndose de la historia del pensamiento y la reflexión científica de la filosofía natural del siglo XVII, vuelve a los resultados benéficos de la metáfora como instrumento del conocimiento (Eco, 1984: 141146, 195-198). De La Grive es, a su vez, la metáfora del sujeto miope del tercer laberinto de la semiótica interpretativa.

Por otra parte, y conexo a este aspecto tan relevante en la novela, el contexto sociohistórico nos coloca frente a otra gran metáfora de carácter espacial y visual. No en vano el autor ha seleccionado como entorno (de su laberinto programado de historias que se cruzan) un momento histórico de la cultura europea en la cual el conocer es un saber y un querer mirar, y donde el espacio adquiere un nivel protagónico en el campo de la reflexión filosófica. El texto, jugando con la mirada geográfica y topográfica (Eco, 1996: 80-81), pasando alternativamente de panorámicas y vistas amplias de espacio exterior hasta descripciones de lugares internos y más estratificados verticalmente y en profundidad que implican acercamientos y reconocimientos de objetos particulares, va delimitando progresivamente un espacio donde la perspectiva del protagonista se vuelve más nítida y menos obstruida. El progresivo aumento del campo perceptivo de Roberto De La Grive será no sólo visual sino acústico, olfativo y táctil hasta las secuencias finales de transformación y transubstanciación corporal. Junto a la mirada geográfica, casi siempre mediada por mapas y signos cartográficos, y la mirada topográfica, se dispone de una mirada microscópica, lo cual constituye un dato impor- 
tante para redefinir la novela dentro de una semiótica del espacio: el coral se convierte en microcosmos y metáfora del espacio del universo. Roberto se configura como actante y como actor en esa confluencia e intermitencia textual entre estos tres tipos de miradas. Miradas que, desde un punto de vista teórico, son también miradas semióticas por cuanto estarán inscritas en un modelo implícito del signo y mediadas por un proceso de generación de interpretantes. En esta novela, en particular, la metáfora como artificio e instrumento cognoscitivo garantiza ese proceso continuo de mediación entre los objetos dinámicos y los interpretantes que el sujeto produce. Un proceso de interpretación que abandona finalmente la idea (desde Adso de Melk hasta Roberto De La Grive y Baudolino) de alcanzar un interpretante lógico final, definitivo: un genus generalissimus.

Desde la perspectiva global que hemos adoptado en este estudio y si intentamos proceder en un movimiento que desde el texto ficcional se proyecta hacia los textos teóricos propiamente dichos, debemos insistir en la presencia de un personaje, un sujeto de la semiosis que se define continuamente como un sujeto del reconocimiento del mundo. Sobre esta dimensión semio-pragmática se articula y se organiza también el referente espacial en su vertiente real o imaginaria. El saber y querer hacer semiósico de Roberto De La Grive se apoya en un trabajo casi permanente de reconocimiento del mundo (visual, sonoro, táctil, olfativo). Un nuevo mundo que debe percibir a través de descripciones y categorizaciones salvajes, construidas sobre rasgos pre-categoriales más o menos constantes (Eco, 1997: 200-201 y Violi, 1997, 2.2.2.3). La Isla y su entorno marino es el espacio destinatario final de una travesía de adquisición de competencia que configura el saber enciclopédico de un sujeto observador para ponerlo literalmente a prueba, frente a frente a la substancia, el continuum de un universo espacial y temporal aún no segmentado por el código.

La elección temática y figurativa del filósofo amateur, del personaje $\mathrm{cu}$ rioso e itinerante (Raimondi, 2002: 32) que atraviesa y usa los espacios como lugares de observación y de reflexión sobre la constitución del signo, si bien en otras modalidades discursivas y figurativas, ha sido puesta en escena en las otras novelas de Eco. Adso de Melk, en un contexto enciclopédico diverso, conserva estos rasgos fundamentales, así como también Casaubon en Il péndolo di Foucault. Quizás De La Grive sea la figura actoral más acentuada de este sujeto interpretante enmarañado en sus propios laberintos o mejor, confinado por la intentio auctoris en la condición espacial oximórica del confinamiento y de la apertura interpretativa. ¿Recuerda el amable lector el juego de contrarios en títulos como La estructura ausente, Obra abierta o Los límites de la interpretación? 


\section{REFERENCIAS BIBLIOGRÁFICAS}

BAJTín, Mijail (1989). Teoría y estética de la novela. Madrid: Taurus.

BARTHES, Roland (1966). Análisis estructural del relato. Buenos Aires: Tiempo Contemporáneo.

Blumemberg, Hans (1984). La leggibilitá del mondo. Il libro come metáfora della natura. Bologna: Il Mulino.

ECO, Umberto (1981). El nombre de la rosa. Barcelona: Lumen.

- (1984). Semiotica e filosofia del linguaggio. Torino: Einaudi.

- (1988). Semiótica y filosofía del lenguaje. Barcelona: Lumen.

- (1992). Los límites de la interpretación. Barcelona: Lumen.

- (1994). L'isola del giorno prima. Milano: Bompiani (La isla del día de antes, Barcelona: Plaza \& Janés, 1997; edición por la que cito).

- (1997). Kant e l'ornitorinco. Milano: Bompiani.

- (1999). Kant y el ornitorrinco. Barcelona: Lumen.

- (2000). Baudolino. Milano: Bompiani.

Foucault, Michel (1968). Las palabras y las cosas. México: Siglo XXI Editores.

GeninASCA, Jacques (1984). «Le régard esthétique». Actes Semiótiques 58, CNRS.

GÓMEZ DE LiAÑo, Ignacio (2001). Athanasius Kircher: itinerarios del éxtasis. Madrid: Siruela.

HAMON, Philippe (1981). Introduction a l'analyse du descriptif. Paris: Seuil.

MANGIERI, Rocco (1994). Escenarios y actores urbanos: elementos de semiótica urbana. Caracas: Fundación para el Desarrollo de las Artes (FUNDARTE).

PeIRCE, Ch. Sanders (1931-1958). Collected Papers. Cambridge: Harvard University Press.

POPPER, Karl (1972). La lógica de la investigación científica. Madrid: Tecnos.

- (1974). Conocimiento objetivo. Barcelona: Paidós.

RAIMONDI, Ezio (2002). El museo del discreto. Madrid: Akal. 
Romera CASTILlo, José et alii, eds. (1995). Bajtín y la literatura. Madrid: Visor Libros.

Roob, Adam (1997). El museo hermético: Alquimia y mística. Colonia: Taschen.

SoBel, Dava (1999). Longitudine. Milano: Rizzoli.

ViCENTE GómEZ, Francisco (1998). El concepto de autor en Mijail Bajtín. Mérida: Cuadernos de Documentación/Universidad de Los Andes.

VIOLI, Patrizia (1997). La spazialitá in moto. Per una semiótica dei verbi in movimiento. Versus 73-74 (Milano: Bompiani).

NOTA: Este artículo es parte de la tesis de doctorado titulada Laberintos, islas, péndulos: espacio y narratividad en la obra de U. Eco, defendida en la Universidad de Murcia (España), en 2001, de pronta aparición en su redacción integral. El autor agradece las sugerencias e ideas estimulantes de Francisco Vicente Gómez (director de la tesis), José Romera Castillo, Jenaro Talens, Estanislao Ramón Trives y Francisca Pérez Carreño, colegas y amigos en el espacio de la semiótica y la estética.

Hemos utilizado la abreviatura LiDDA para referirnos a segmentos extraídos de la novela La isla del día de antes, de Umberto Eco. 